УДК 338. 637.1

\title{
MONITORING THE STATUS AND PROSPECTS FOR DEVELOPMENT OF EXPORT POTENTIAL OF THE DAIRY INDUSTRY OF UKRAINE
}

\author{
O. Pietukhova, Ju. Zhuravel \\ National University of Food Technologies
}

\begin{tabular}{l}
\multicolumn{1}{c}{ Key words: } \\
Export \\
Export potential \\
Dairy products \\
Import \\
Quality \\
Export valuation \\
\hline \multicolumn{1}{c}{ Article history: } \\
Received 13.07.2018 \\
Received in revised form \\
30.07.2018 \\
Accepted 17.08.2018 \\
\hline Corresponding author: \\
O. Pietukhova \\
E-mail: \\
ompetukhova@bigmir.net
\end{tabular}

\begin{abstract}
The paper is devoted to the actual issue concerning the export potential of the dairy industry of Ukraine. The concept of "export potential" is considered. The export potential of the food industry of Ukraine is found to be one of the important directions of development of export possibilities of the national economy.

This paper investigates the dairy industry of Ukraine. It is decided to redirect their export potential towards the European market. The state of the dairy market of our country is investigated, namely the reasons for the termination of inefficient enterprises activity are presented. The approaches of different scientists concerning definition of category "export potential", as well as methods for its estimation are analyzed. The export activity of Ukraine is analyzed, new and potential markets of products are analyzed. Ukraine's commercial dairy industry is beginning to recover from a sharp decline during recent years, producing higher quality milk and tapping into new foreign markets. There were found out both the most promising and appropriate products which Ukrainian enterprises can present to Europe.

The main reasons that hinder Ukraine's exit to international markets are investigated. The volumes of export and import of dairy products in Ukraine are analyzed. The geographical structure of exports and imports is considered. The main countries that export their dairy products to Ukraine were identified. And also the main problem of development of dairy products is determined. The main directions concerning increase of effective realization of export potential of our country are offered. As a result of the study, the growth of the export potential of food is stated to be a determining factor in the development of foreign trade relations, an important link in the foreign trade exchange.
\end{abstract}

DOI: $10.24263 / 2225-2924-2018-24-4-10$ 


\title{
МОНІТОРИНГ СТАНУ ТА ПЕРСПЕКТИВИ РОЗВИТКУ ЕКСПОРТНОГО ПОТЕНЦІАЛУ МОЛОЧНОЇ ПРОМИСЛОВОСТІ УКРАЇНИ
}

\author{
О.М. Пєтухова, Ю.О. Журавель \\ Національний університет харчових технологій
}

У статті досліджено експортний потенціал молочної промисловості України. Розглянуто поняття «експортний потенціал». Виявлено, щзо експортний екпотениіал харчової промисловості України є одним із важливих напрямів розвитку експортних можливостей національної економіки.

Проаналізовано стан молочного ринку нашої країни, наведено причини припинення діяльності неефективних підприємств. З’ясовано, щуо, незважаючи на політичну та економічну нестабільність в Україні, торгівля молочними продуктами краӥни починає відновлюватися, розвивається молокопереробна промисловість, виробляючи якісні молочні продукти та виводячи їх на нові зовнішні ринки. Проаналізовано географічну структуру експорту молокопродукиії з України, визначено основні країни-експортери. Досліджено географічну структуру імпорту та визначено основні країни, які експортують свою молочну продукиію в Украйну. Проведено аналіз експортованих та імпортованих Украйною молочних товарів у натуральному та вартісному вимірах. Визначено найбільш перспективні продукти, які украӥнські підприємства можуть експортувати Свропі.

3'ясовано основні причини, які гальмують вихід України на міжнародні ринки, а також проблеми розвитку експорту молочної продукції. Запропоновано напрями підвищення конкурентоспроможності та розвитку підприємств молокопереробного підкомплексу та розвитку експортного потенціалу нашої країни. Доведено необхідність дотримання вимог Свропейського Союзу щзодо молочної продукції та подальшого розвитку ї̈ експорту. Доведено, щзо зростання експортного потенціалу молочної промисловості України - визначальний фактор у розвитку зовнішньоторговельних зв'язків, ш⿻о $\epsilon$ важливою ланкою у зовнішньоторговельних відносинах.

Ключові слова: експорт, експортний потенціал, молочна продукція, імпорт, якість, оиінка експорту.

Постановка проблеми. Україна $є$ потужною державою, яка має великі перспективи в різних сферах економіки, зокрема у розвитку агропромислового комплексу. Одним із стратегічно важливих секторів для України є молокопродуктовий. Перш за все він забезпечує здоровий і повноцінний розвиток нації, адже молочні продукти є незамінними в збалансованому харчуванні людини. Молокопереробний підкомплекс України має потужний потенціал для того, щоб завоювати лідируючі позиції не тільки на внутрішньому ринку, але також і на зовнішньому.

На жаль, відсутність підтримки з боку держави значно гальмує розвиток експортного потенціалу підприємств галузі. Для зміни ситуації необхідне 
вдосконалення бюджетної, податкової, інвестиційної фінансово-кредитної політики держави та внесення відповідних змін до законодавчої бази, які нададуть можливість товаровиробникам змінити на краще існуючу ситуацію на ринку молока [8].

Аналіз останніх досліджень і публікацій. Питанням дослідження експортного потенціалу молокопродуктового сектору України приділяється значна увага в працях таких науковців, як: О. Гуторов [1], О. Козак [3], В. Ладика [4], Л. Ліпич [5], О. Маслак [6], Л. Нейкова [8], А. Солошонок [11], Т. Хворост [12], С. Щербина [13] та інших. Однак велика кількість проблем залишаються досі не вирішеними, а Україна поступово перетворюється в імпортера молочної продукції, не використовуючи власний експортний потенціал і знищуючи національне молокопродуктове виробництво.

Мета дослідження: проаналізувати експотр-імпорт молочної продукції, визначити основні країни-експортери та країни-імпортери, з'ясувати проблеми експорту молочної продукції та розробити рекомендації щодо розвитку молокоперобної промисловості України.

Викладення основних результатів дослідження. В Економічній енциклопедії за редакцією С.В. Мочерного поняття «експортний потенціал» визначається як «здатність єдиного народногосподарського комплексу країни виготовляти максимальну кількість конкурентоспроможних товарів на світовий ринок, надавати якнайбільше якісних послуг і виконувати необхідну кількість робіт на замовлення іноземних країн і компаній» [2].

Е. Радченко, досліджуючи погляди науковців на сутність поняття «експортний потенціал» 3 позицій ресурсного, результативного, ринкового та системного підходів, приходить до висновку щодо відсутності визначення зазначеної категорії як узагальнюючого поняття і зазначає, що «існування багатьох визначень і підходів до трактування цього поняття свідчить про надзвичайну актуальність розглянутого питання» [10].

На жаль, у науковій літературі також відсутня єдина методика оцінки експортного потенціалу. Це пов'язано, на наш погляд, з неможливістю однозначної кількісної оцінки експортного потенціалу через певну суб'єктивність цього поняття, відсутність прямої залежності між потенціалом і ринковою позицією підприємства, станом галузі, а тим більше - країни.

Молочна галузь належить до провідних у харчовій і переробній галузях промисловості України й відіграє важливу роль в економіці держави та забезпеченні населення продуктами харчування першої необхідності. Молокопереробний комплекс виконує низку важливих функцій: забезпечує суспільство незамінними продуктами харчування; безперервно поповнює обігові кошти товаровиробників, бюджет країни, постачає сировину для інших сфер виробництва та, як результат, формує привабливий за обсягами ринок. Це пов'язано $з$ тим, що молочна продукція займає важливе місце в споживанні: частка витрат на молочні продукти становить у середньому у світі $15 \%$ від загальних витрат на харчування [5].

Досліджуючи сучасний стан ринку молока та молокопродуктів можемо спостерігати, що останніми роками відбувається припинення діяльності неефек- 
тивних підприємств з переробки молока та виготовлення молочної продукції 3 огляду на такі причини:

- закриття доступу до ринку одного з найбільших споживачів української молочної продукції - Росії;

- зниження купівельної спроможності населення, що могло бути спричинено економічною ситуацією в країні;

- зменшення географічних розмірів ринку через втрату контролю над частиною території України;

- недостатне розуміння сучасних вимог до якості та непристосованість молочного сектору України до того, щоб виробляти молочні продукти, які б мали попит за межами країн СНД.

Протягом 2015 р. Україна відкрила для себе кілька нових ринків, дозволи на експорт у Китай, Казахстан та країни ЄС отримали численні компанії, це певним чином компенсувало втрату російського ринку [7]. Відповідно, позитивні результати в експорті мають великі та потужні підприємства, які мають ефективно налагоджену організацію всіх виробничих та управлінських процесів. Саме після припинення співпраці з Російською Федерацією вітчизняні виробники зрозуміли, що для більш ефективнішої зовнішньоекономічної діяльності вони мають кардинально змінити свій підхід до бізнесу, насамперед це стосується зміни ментальності керівництва. На нашу думку, підприємства, які мають проблеми в досягненні позитивних результатів, - це ті, які не розвивають свою діяльність у напрямі підвищення кваліфікації та знань персоналу, не приділяють належної уваги підвищенню якості продукції, а зациклені на старих технологіях і техніці та відсутності адаптації до сучасних потреб.

На думку С.В. Щербини [13], основними причинами, які змушують молокопереробні підприємства України здійснювати подальше освоєння міжнародних ринків молочної продукції, є такі:

1) міжнародні ринки молочної продукції відкривають значні можливості для нарощування виробництва, збільшення доходів, отримання додаткових конкурентних переваг за рахунок ефекту масштабу;

2) вихід на зовнішні ринки дасть змогу диверсифікувати ризики як комерційного, так і політичного характеру;

3) освоєння зовнішніх ринків має стати стимулом впровадження міжнародних стандартів якості у процесі виробництва.

Аналіз експортованих та імпортованих Україною молочних товарів дасть можливість зрозуміти, які товари користуються попитом на іноземному ринку, а які - ні. Цікавою $є$ також географічна структура експорту та імпорту.

Аналіз географічної структури експорту з України молокопродукції в 2017 р. (рис. 1) показав, що найбільшим експортером молочних продуктів $\epsilon$ Казахстан, який займає 17,6\% загальної структури експорту, а також Молдова - $12,1 \%$. Найменше українських молокопродуктів експортують Філіппіни (1\%), Непал $(1,2 \%)$, Індія $(1,5 \%)$, Нідерланди $(1,6 \%)$, Алжир $(1,7 \%)$ i Росія $(1,8 \%)$. 


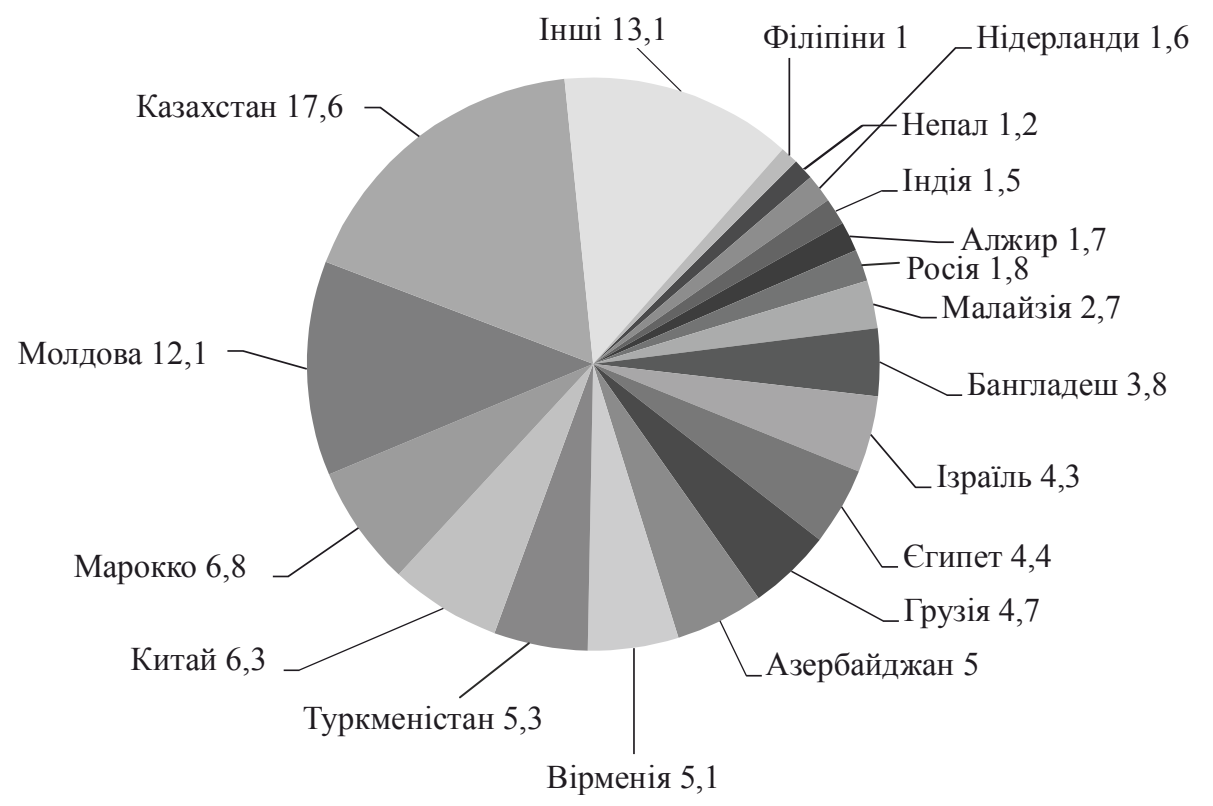

Рис. 1. Географічна структура екпорту з України молокопродукції в 2017 р., складено авторами за даними [9]

Слід зазначити, що поряд із експортом, Україна здійснює також імпорт молочної продукції.

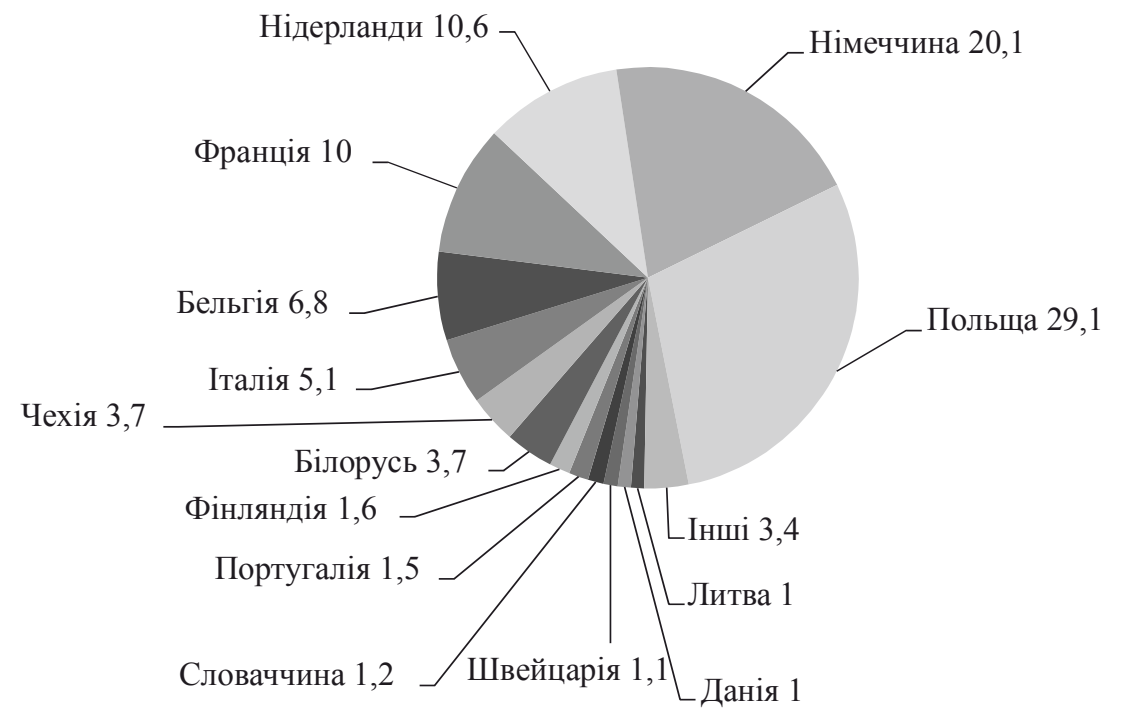

Рис. 2. Географічна структура імпорту в Україну молокопродукції в 2017 р., складено авторами за даними [9]

Географічна структура імпорту в Україну молокопродукції за 2017 р. (рис. 2) свідчить, що найбільше молочних продуктів Україна імпортує з Польщі $(29,1 \%)$ і Німеччини, що становить $20,1 \%$ загальної структури імпорту. Най- 
меншу частку продукції імпортує з таких країн, як: Данія (1\%), Литва (1\%), Швейцарія (1,1\%), Словаччина (1,2\%), Португалія $(1,5 \%)$ і Фінляндія $(1,6 \%)$.

Аналізуючи експорт-імпорт молочних продуктів за 2016-2017 pp. у розрізі товарних груп (табл. 1), помічаємо, що експорт всіх видів продукції зазнає позитивних змін.

Таблиия 1. Обсяги експорту-імпорту молокопродуктів в Україні за 2016-2017 pp., тонн, складено авторами за даними [8]

\begin{tabular}{|c|c|c|c|c|c|c|c|c|}
\hline $\begin{array}{c}\text { Найменування } \\
\text { продукції }\end{array}$ & \multicolumn{2}{|c|}{ Експорт за роками } & \multicolumn{2}{|c|}{ Відхилення } & \multicolumn{2}{|l|}{ Імпорт за роками } & \multicolumn{2}{|c|}{ Відхилення } \\
\cline { 2 - 10 } & 2016 & 2017 & $+/-$ & $\%$ & 2016 & 2017 & $+/-$ & $\%$ \\
\hline $\begin{array}{c}\text { Молоко та вершки, } \\
\text { незгущені та без } \\
\text { додання цукру чи } \\
\text { інших підсолоджу- } \\
\text { вальних речовин }\end{array}$ & 10489,2 & 14061,5 & 3572,3 & 34,1 & 586,4 & 836,5 & 250,1 & 42,7 \\
\hline $\begin{array}{c}\text { Маслянка, } \\
\text { коагульовані молоко } \\
\text { та вершки, йогурт, } \\
\text { кефір та інші } \\
\text { ферментовані або } \\
\text { сквашені }\end{array}$ & 2853,8 & 3710,7 & 856,9 & 30 & 2587,3 & 3611,6 & 1024,3 & 39,6 \\
\hline Молочна сироватка & 23871,8 & 31937 & 8065,2 & 33,8 & 728,7 & 1383,3 & 654,6 & 89,8 \\
\hline $\begin{array}{c}\text { Масло вершкове та } \\
\text { інші жири, вироблені } \\
\text { з молока; молочні } \\
\text { пасти }\end{array}$ & 12032,4 & 30441,5 & 18409,1 & 152,9 & 1083,0 & 751,4 & $-331,6$ & $-30,6$ \\
\hline $\begin{array}{c}\text { Сири всіх видів і } \\
\text { кисломолочний сир }\end{array}$ & 8050,8 & 9050,8 & 1000 & 12,4 & 7058,4 & 10010,3 & 2951,9 & 41,8 \\
\hline Всього & 57298 & 89201,5 & 31903,5 & & 12043,8 & 16593,1 & 4549,3 & \\
\hline
\end{tabular}

Найбільша динаміка спостерігається стосовно масла вершкового - 152,9\%. Також відбулося значне зростання експорту молока (на 34,1\%), молочної сироватки (на 33,8\%) і маслянки (на 30\%). Найменше, порівняно 3 досліджуваною продукцією, зріс експорт сирів на 12,4\%. Слід відзначити, що Україна експортує широкий товарний асортимент молочної продукції і $є$ одним iз потужних експортерів молочної продукції.

Основними імпортними молочними продуктами $\epsilon$ молочна сироватка, імпорт якої зріс на 89,8\%, молоко та вершки, імпорт яких зріс на 42,7\%. Також в 2017 р., порівняно з 2016 р., імпортували велику кількість сирів, частка яких зросла на 41,8\% і маслянки, зростання імпорту якої сягнуло 39,6\%. Помічаємо, що значно менше Україна почала імпортувати масла вершкового (в 2016 р. - 1083 т., а в 2017 р. — зменшення до 751,4 т., що становить 30,6\%).

На наш погляд, доцільно проаналізувати обсяги експорту та імпорту молокопродуктів в Україні за 2016-2017 роки також у вартісному виразі (табл. 2).

Отже, в 2016 р. експорт української молочної продукції (табл. 2), становив 84 204,6 тис. дол., а в 2017p. зріс до 201111 тис. дол. США.

Загалом, незважаючи на те, що Україна експортує значну кількість молочної продукції, помічаємо, що зростають також показники імпорту, особливо це відобразилося на таких продуктах, як сири всіх видів (57,8\%), молочна 
сироватка (47,5\%), маслянка, коагульовані молоко та вершки, йогурт, кефір (42,5\%), молоко та вершки (36,1\%), сири всіх видів (27,5\%). У цілому загальна вартість імпортованих молочних продуктів у 2017 p. зросла 340276,5 тис. дол. до 6 1037,7 тис. дол., тобто на 20 761,2 тис. дол. США.

Таблиия 2. Експорт та імпорт молокопродуктів в Украйні за 2016-2017 рр., тис. дол. США, складено авторами за даними [8]

\begin{tabular}{|c|c|c|c|c|c|c|c|c|}
\hline \multirow{2}{*}{$\begin{array}{l}\text { Найменування } \\
\text { продукції }\end{array}$} & \multicolumn{2}{|c|}{ Експорт за роками } & \multicolumn{2}{|c|}{ Відхилення } & \multicolumn{2}{|c|}{ Імпорт за роками } & \multicolumn{2}{|c|}{ Відхилення } \\
\hline & 2016 & 2017 & $+/-$ & $\%$ & 2016 & 2017 & $+1-$ & $\%$ \\
\hline $\begin{array}{c}\text { Молоко та вершки, } \\
\text { незгущені та без } \\
\text { додання цукру чи } \\
\text { інших підсолоджу- } \\
\text { вальних речовин }\end{array}$ & 5430,2 & 9733,7 & 4303,5 & 79,3 & 1061,5 & 1444,2 & 382,7 & 36,1 \\
\hline $\begin{array}{c}\text { Маслянка, } \\
\text { коагульовані молоко } \\
\text { та вершки, йогурт, } \\
\text { кефір та інші } \\
\text { ферментовані або } \\
\text { сквашені }\end{array}$ & 2582,1 & 4179,8 & 1597,7 & 61,9 & 3942,4 & 5617,0 & 1674,6 & 42,5 \\
\hline Молочна сироватка & 14340,4 & 24827,8 & 10487,4 & 73,1 & 1605,9 & 2368,6 & 762,7 & 47,5 \\
\hline $\begin{array}{c}\text { Масло вершкове та } \\
\text { інші жири, вироблені } \\
\text { з молока; молочні } \\
\text { пасти }\end{array}$ & 37534,0 & 129859,2 & 92325,5 & 245,9 & 3790,1 & 4479,1 & 689 & 18,2 \\
\hline $\begin{array}{c}\text { Сири всіх видів і } \\
\text { кисломолочний сир }\end{array}$ & 24317,9 & 32510,3 & 8192,4 & 33,7 & 29876,5 & 47128,8 & 17252,3 & 57,8 \\
\hline Всього & 84204,6 & 201111 & 116906 & & 40276,5 & 61037,7 & 20761,2 & \\
\hline
\end{tabular}

Цілком логічно постає питання: що гальмує розвиток експорту молочної продукції? На сьогодні основною слабкою ланкою залишається сировина. Це стосується іiі низької якості, що, у свою чергу, негативно впливає на якість готової продукції та загострює проблему ії збуту, особливо на зовнішньому ринку.

Бажання відкрити європейський ринок спонукає виробників з іншої точки зору поглянути на важливість та необхідність вдосконалення якості продукції. Для того, щоб стати лідером на зовнішньоекономічному ринку, необхідно якісно організовувати виробництво та забезпечити дотримання технологічних процедур, таких як: належна гігієна доїння, умови зберігання та транспортування молока (зокрема дотримання температурного режиму), обов'язкова ідентифікація тварин, здоров'я поголів 'я, облік та утилізація молока тощо.

Відповідно до результатів аналізу експорту та імпорту молокопродуктів постає питання розробки комплексу науково-обгрунтованих економічних та організаційних заходів щодо підвищення конкурентоспроможності молочної продукції та розвитку підприємств молокопереробного підкомплексу. До таких рекомендаційних заходів можемо віднести:

- впровадження інноваційних технологій та реконструкція існуючих господарств із застосуванням сучасних розробок у галузі молочного скотарства (зокрема впровадження сучасних технологій утримання та годівлі тварин); 
- покращення кормової бази на основі органічного землеробства;

- забезпечення взаємовигідних інтеграційних зв'язків «виробництво-переробка-збут» на основі комплексної державної програми розвитку молочної галузі;

- налагодження ефективної системи закупівлі молочної сировини у господарств населення та фермерських господарств, а саме створення пунктів заготівлі молока, які оснащені холодильним та лабораторним обладнанням для проведення первинних аналізів якості молока;

- сприяння та стимулювання проходженню міжнародної сертифікації національними молокопереробними підприємствами;

- надання інформаційної підтримки 3 боку державних органів влади вітчизняним виробникам щодо якості та безпечності молокопродуктів з метою адаптації підприємств галузі до європейських стандартів;

- підвищення рівня кваліфікованості та знань спеціалістів, відповідальних за проведення контролю якості молока та молокопродуктів згідно 3 міжнародними вимогами;

- надання державної підтримки виробникам молочної продукції;

- розробка спеціальних програм кредитування тощо.

У цілому, зважаючи на те, що молоко і молокопродукти є традиційними продуктами харчування для населення багатьох країн світу, і враховуючи, що темпи росту виробництва молока у світі є нижчими, ніж темпи росту чисельності населення, проблема експорту молокопродукції залишається надзвичайно актуальною.

\section{Висновки}

Україна має потужний експортний потенціал, який необхідно підтримувати та розвивати, бо у світі попит на молоко та молочні продукти зростає, а наша країна має всі підстави для того, щоб завоювати більше іноземних ринків. Особливу увагу необхідно звертати на уніфіковані норми, стандарти та правила виробництва, зберігання молочної продукції, а також торгівлі нею відповідно до вимог Європейського Союзу. Також важливе значення має дотримання технічних і санітарних норм вітчизняної продукції, що експортується. Молочний сектор України має великі перспективи розвитку експортного потенціалу, але потрібно прикласти багато зусиль для того, щоб завоювати міжнародні ринки та отримати на них лідируючі позиції.

\section{Лiтература}

1. Гуторов O.I. Світові тенденції розвитку ринку молока / О.І. Гуторов // Вісник Харківського національного технічного університету сільського господарства: Економічні науки. Вип. 112. - Харків : ХНТУСГ, 2011. - С. 3-8.

2. Економічна енциклопедія: у трьох томах / відповід. ред. С.В. Мочерний. - Київ : Видавничий центр «Академія», 2002. - Т. 3. - 952c.

3. Козак О.А. Основні тенденції розвитку світового ринку молока та молочної продукції / О.А. Козак // Економіка АПК. - 2007. — № 3. - С. 149-154.

4. Ладика В. Світовий молочний ринок : стан та перспективи / В. Ладика, О. Маслак // Пропозиція. - 2009. - № 4. - С. 31-33. 
5. Ліпич Л. Моніторинг стану та перспектив розвитку ринку молока й молочних продуктів України / Л. Ліпич, О. Товстенюк, І. Білик // Економічний часопис Східноєвропейського національного університету імені Лесі Українки № 2. - 2016. - С. 56-63.

6. Маслак О. Світові тенденції молочного ринку / О. Маслак, Т. Хворост // Пропозиція. 2010. — № 2. - С. $44-46$.

7. Міністерство аграрної політики та продовольства України [Електронний ресурс] / Офіційний сайт. - Режим доступу : http://www.minagro.gov.ua

8. Нейкова Л.І. Проблеми виходу вітчизняних підприємств молокопереробного підкомплексу АПК на закордонні ринки / Л.І. Нейкова, К.Р. Маноха // Ефективна економіка [Електронний ресурс]. - Електрон. наук. фах. вид. № 12, 2013. - Режим доступу : http://www.economy.nayka.com.ua.

9. Офіційний веб сайт Державної служби статистики України [Електронний ресурс]. Режим доступу: http://www.ukrstat.gov.ua.

10. Радченко E.C. Визначення сутності поняття «експортний потенціал країни» / Е.Є. Радченко // Вчені записки Університету «КРОК». - 2013. - Випуск 34. - С. 205-212.

11. Солошонок А.Л. Національні та світові тенденції розвитку ринку молока і молочних продуктів / А.Л. Солошонок, К.М. Куліш // Продуктивність агропромислового виробництва. економічні науки. - 2013. - Вип. 24. - С. 113-123. - Режим доступу : http://nbuv.gov.ua/j-pdf/Pav_2013_24_19.pdf.

12. Хворост T.B. Розвиток світового та національного ринків молочної продукції / Т.В. Хворост // Ефективна економіка [Електронний ресурс]. - Електрон. наук. фах. вид. № 11, 2014. — Режим доступу : http://www.economy.nayka.com.ua.

13. Щербина С.В. Зовнішньоторговельна політика України та ії вплив на експортний потенціал молокопереробних підприємств / С.В. Щербина [Електронний ресурс]. Режим доступу : http://www.academy.gov.ua/ej/ej13/txts/Scherbina.pdf. 